\title{
Inflation Targeting in Emerging Economies And its Applicability to the Egyptian Economy
}

\author{
Dr. Eman Ahmed Hashem \\ Lecturer - Economic Department \\ Faculty of Commerce \\ Ain Shams University \\ Arab Republic of Egypt
}

\begin{abstract}
:
Inflation targeting has been widely adopted in both developed and emerging economies.

Inflation targeting is one of the operational frameworks for monetary policy aimed at attaining price stability as a primary goal of monetary policy, while other goals are subordinated to the achievement of the inflation target, which comes as a first priority. An important element of the inflation targeting framework is transparency of the monetary policy strategy through communication with the public and the markets about plans, objectives, and decisions of the monetary authorities.
\end{abstract}

The main aim of this study is to assess the applicability to apply Inflation targeting in Egypt. Comparing the current position of Egypt with some emerging market economies.

In order to achieve this aim, the paper discusses the definition of inflation targeting and the prerequisites to apply inflation targeting. Then we illustrate two case studies in applying inflation targeting in emerging economies (Chile and Brazil). To try to answer the main question in this study. Is Egypt ready to apply inflation targeting? and the lessons that can be learned from emerging market economies to apply inflation targeting successfully.

The study concludes that the success of inflation targeting in emerging market economies required not only a focus on good communication and transparency by the Central bank, but also supportive policies to develop strong fiscal, financial and monetary institutions.

In addition, the study concluded that the preconditions of inflation targeting are moderately met in Egypt. In addition, it needs more efforts to improve transparency and accountability, ensuring greater independence of the $C B$ and developing strong fiscal and financial institutions.

Keywords: Egypt, Emerging economies, Inflation targeting (IT)

\section{Introduction:}

Inflation targeting has gained popularity around the world since its implementation in the early 1990s. A growing number of countries, especially emerging countries, implement this regime implying a greater concern of central banks over price stability, low inflation, and sustainability in growth.

Lessons from the international experiences suggest that preconditions for the success of inflation targeting are central bank independence and exchange rate flexibility, political commitment and the institutional set up and economic structure. Many emerging countries lack these preconditions for a proper implementation of the inflation targeting regime. 
Therefore, it is argued that emerging countries face a greater challenge in achieving inflation targets compared with developed countries.

Despite these challenges, inflation targeting has been successfully in promoting macroeconomic stability in a number of emerging market countries.

Since the central bank of Egypt announced in 2005 the adoption of inflation targeting as a new monetary policy regime, there has been a continued controversy surrounding its ability to conduct this new monetary policy.

So, we compare the position of Egypt to the emerging market economies in the early days of their adoption of IT regime to answer the question Is Egypt satisfy prerequisites of IT regime?

The paper is organized as follows:

Chapter One: Overview of Inflation Targeting which includes the definition of inflation targeting, advantage and disadvantage of Inflation targeting and the prerequisites to apply Inflation targeting.

- Chapter Two: Inflation Targeting in the Emerging Economies: in this chapter we illustrate two case studies in applying inflation targeting: Chile and Brazil.

- Chapter Three: Inflation Targeting in Egypt: In this chapter, we try to answer the main question in this study: Is Egypt ready for inflation targeting and illustrate the lessons that can be learned from some emerging market economies to apply inflation targeting successfully.

\section{Methodology:}

This paper followed the descriptive and analytical methods.

- Descriptive Method: to describe the definition of inflation targeting, advantage and disadvantage of targeting inflation and the prerequisites to apply inflation targeting.

- Analytical Method: to assess the applicability to apply inflation targeting in Egypt and comparing the current position of Egypt with some emerging market economies.

\section{Chapter 1: Overview of Inflation Targeting Policy}

\section{Definition of Inflation Targeting:}

Inflation targeting represents a strategy of monetary policy that requires the central bank to establish a target for the rate of inflation for a certain period of time and to achieve it using monetary instruments, so that price stability is obtained.

Inflation targeting policy encompasses five main elements: (i) public announcement of medium term numerical targets for inflation; (ii) an institutional commitment to price stability as a primary goal of monetary policy; (iii) an information inclusive strategy in which many variables, and not just monetary aggregates or the exchange rate, are used for deciding the setting of policy instruments; (iv) increased transparency of the monetary policy strategy through the communication with the public and the markets about plans, objectives, and decisions of the monetary authorities; and (v) increased accountability of central bank for attaining its inflation targets.(Awad,2009) 


\section{Advantages and Disadvantages of Inflation Targeting:}

Proponents of inflation targeting argue that it yields a number of benefits compared to other strategies.

- Inflation targeting can improve credibility and helps creating clear inflation expectations rapidly: a low inflation level is the primary goal of monetary policy and it requires greater transparency to compensate the operational freedom that it offers. Inflation targeting can help economic agents better understand and evaluate the performance of the central bank being easily observable and understandable than other targets. (Vasilescu, 2010)

- Inflation Targeting Provides More Flexibility: since inflation cannot be controlled instantaneously, the target on inflation is typically interpreted as a medium- term objective. This implies that central banks pursue the inflation target over a certain horizon. By focusing on keeping inflation expectations at the target.( Short- term deviations of inflation from the target are acceptable and do not necessarily translate into losses in credibility).

- Inflation Targeting Involves a Lower Economic Cost: the output costs of policy failure under some alternative monetary commitments such as exchange rate pegs can be very large, usually involving massive reserve losses, high inflation, financial and banking crises, and possibly debt defaults. In contrast, the output costs of failing to meet the inflation target are limited to inflation that is temporarily higher than targeted and growth that is temporarily slower, as interest rates are raised to bring inflation back to target. (Batini and laxion, 2006)

Critics have argued that inflation targeting has disadvantages and imposes excessive constraints on central banks:

- The forward-looking nature of an inflation targeting requires taking into consideration the potentially long lags between changes in monetary policy and their influences on inflation. Monetary policy needs to be able to respond to the deviations between the inflation target and the inflation forecast at various policy horizons.

The central bank has to have access to both an effective inflation-forecasting model and policy instruments, which influence the inflation forecast with reasonable precision. In addition, since the forward-looking nature of inflation targeting framework brings some uncertainties into the policy decision process, it permits more discretion on the part of the central bank than an exchange rate targeting or monetary targeting framework.

Therefore, this discretion may allow policy makers to follow overly expansionary policies. (IMF, 1998)

- Inflation targeting implies high exchange rate volatility; because it elevates price stability to the status of the primary goal for the central bank, inflation targeting requires benign neglect of the exchange rate. If this is the case, it could have negative repercussions on exchange rate volatility and growth. (Batini and laxion, 2006)

- Although the rigid structure of the inflation targeting regime provides a better cyclical adjustment of the economy, this discretion may lead to inefficient output stabilization. 
Inflation Targeting in Emerging economies ...

\section{Inflation Targeting Prerequisites:}

There are four prerequisites to implement an inflation-targeting framework for monetary policy.

\section{1- The Independence of the Central Bank:}

The fundamental requirement of an inflation targeting framework is that the central bank must be given complete independence to adjust freely its instruments of monetary policy toward attainment of the objective of low inflation. The independence does not mean full independence but implies at least instrumental independence which permits greater discretion in the conduct of monetary policy. There should not be any political pressure on the central bank to raise the rate of economic growth in such a way that is inconsistent with the achievement of the inflation target. (Tutar, 2002)

The essential features of an independent central bank can be summarized under five broad headings:

i. A very well defined primary objective that takes priority over all other objectives.

ii. Political independence for the design of monetary policy.

iii. Economic independence for the execution of monetary policy.

iv. Financial autonomy and

v. Clearly defined accountability procedures

\section{2- Financial System Stability:}

Financial stability enables monetary policy to pursue the inflation targets and not be sidetracked by concerns about the health of the financial sector. Financial system stability bolsters the credibility of monetary policy, thereby helping to anchor inflation expectations to the inflation target.

Two potential concerns for an inflation targeting central bank are raised by financial stability. First, large bailouts of financial institutions through the provision of central bank liquidity could raise concerns that the central bank might not be able to fully sterilize the monetary impact, and thus could generate inflation pressures. Second, the central bank's ability to pursue the inflation target could be constrained if an increase in interest rates needed to tighten monetary conditions threatens the health of systemically important financial institutions or markets owing to highly leveraged or exposed balance sheets. (IMF, 2002)

Therefore, it is important for a country before it adopts a new monetary policy to undergo a financial reform program, in order to be able to attain the goals of the new policy. Strengthening the financial system requires several types of institutional reforms. For instance, prudential regulation of the banking and financial system must be strengthened to ensure that currency mismatches are limited, in order to prevent currency devaluations from destroying balance sheets. Other problems need to be resolved, such as the problem of non performing loans, and other government policies may be needed to limit liability euroization or dollarization or at least reduce the incentives for it. Financial markets should also be sufficiently developed to enable inflation targeting to be implemented using market based instruments. . ( Abdel Ghaffar, 2007) 


\section{3- Accountability and Transparency:}

Accountability is an essential prerequisite to implement an inflation targeting framework; because policy transmission lags make it difficult for the public to monitor policy performance on an ongoing basis. This stands in marked contrast to policy frameworks with explicit intermediate targets, such as exchange rate and monetary targeting regimes, where performance against the targets can be easily monitored on an ongoing basis. In addition, accountability helps to insulate monetary policy from outside political pressures.

In order to ensure that the public has enough information to hold the central bank accountable, the monetary policy framework under inflation targeting must be transparent.

The inflation target needs to be made explicit and public the definition of the inflation target should comprise not only the numerical target values, but also the underlying price index and time horizon in which the target is to be achieved. (IMF, 2002)

It is very important for the central bank to inform the public about every circumstance connected to its policy in order to make its goals and instruments clear and controllable. The public can use this information to form better expectations about future policy actions and keep track of the central bank's performance.

\section{4- Forecasting Capabilities:}

An important prerequisite for the success of monetary policy conduct is the ability to forecast future inflation.

The adoption of inflation targeting by announcing some targets for inflation to be reached in the future and the way it will be used to reach such target requires:

i. A model for inflation forecasting and inflation projections have to be set up in advance;

ii. Central bank needs to have clear vision regarding monetary policy transmission mechanisms and the associated lags; and

iii. The availability of an inclusive and updated database with high quality economic variables is an indispensable task. (Awad,2009)

\section{Alternative Approaches to Forecasting Inflation:}

\section{1- The Phillips Curve Model (Output Gap Models)}

The expectations augmented Phillips curve model expresses inflation as a function of its own lagged values (capturing expectations), the output gap (a demand pressure variable), and changes in the relative prices of food and energy.

We have two prototype Phillips curve forecasts. The first is triangle model. In the triangle model, inflation depends on lagged inflation, the unemployment rate Ut, and supply shock variables $\mathrm{Zt}$

$$
\pi_{\mathrm{t}+1}=\mu+\alpha^{\mathrm{G}}(\mathrm{L}) \pi_{\mathrm{t}}+\beta(\mathrm{L}) \mathrm{U}_{\mathrm{t}+1}+\gamma(\mathrm{L}) \mathrm{Z}_{\mathrm{t}}+\mathrm{V}_{\mathrm{t}+1}
$$

The second prototype Phillips curve model is direct version of triangle model without the supply shock variables and without the step- function restriction on the coefficients. 
This model is an autoregressive distributed lag (ADL) model in which forecasts are computed using the direct regression. (Stock \& Watson, 2005)

$$
\pi^{\mathrm{h}}{ }_{\mathrm{t}+\mathrm{h}}-\pi_{\mathrm{t}}=\mu^{\mathrm{h}}+\alpha^{\mathrm{h}}(\mathrm{L}) \Delta \pi_{\mathrm{t}}+\beta^{\mathrm{h}}(\mathrm{L}) \mathrm{U}_{\mathrm{t}}+\mathrm{V}^{\mathrm{h}}{ }_{\mathrm{t}+\mathrm{h}}
$$

\section{2- Money Gap Models:}

The price equation based on money demand views inflation as being caused by money growth in excess of growth in real money demand.

$\operatorname{Ln} \mathrm{P}_{\mathrm{t}}=\ln \mathrm{M}_{\mathrm{t}}^{\mathrm{s}}-\ln \mathrm{md}_{\mathrm{t}}$

\section{Where:}

$\mathrm{Md}_{\mathrm{t}}$ : is the public's demand for real money.

$\mathrm{M}_{\mathrm{t}}$ : actual level of money balances

$\mathrm{P}_{\mathrm{t}} \quad$ : the price level.

And $\ln :$ is the natural logarithm

This equation says that the price level is determined by the actual level of money balances in excess of real money demand.

Thus in this equation an increase in nominal money stock given real money demand causes the price level to rise, and a rise in the public's real money demand given the fixed money stock causes the price level to fall.

The public's demand for real money balances depends positively on real income $\mathrm{Y}$ (which measures the real value of transactions financed by money) and inversely on the opportunity cost variable defined as the difference between the market rate of interest ( R) and the own rate of money (RM) (Mehra, 1988)

Ln $\mathrm{md}_{\mathrm{t}}=\mathrm{a}+\mathrm{b} \ln \mathrm{y}_{\mathrm{t}-\mathrm{c}}(\mathrm{R}-\mathrm{RM})_{\mathrm{t}}$

So

$\operatorname{Ln} \mathrm{P}_{\mathrm{t}}=-\mathrm{a}+\ln \mathrm{M}_{\mathrm{t}}-\mathrm{b} \ln \mathrm{y}_{\mathrm{t}}+\mathrm{c}(\mathrm{R}-\mathrm{RM}) \mathrm{t}$

The inflation equation consistent with this approach could be expressed as:

$\mathrm{P}_{\mathrm{t}}{ }=\mathrm{K}_{0}+\sum_{s=0}^{n 1} K_{1 \mathrm{~S}} \mathrm{M}_{\mathrm{t}-\mathrm{s}}-\sum_{s=0}^{n 2} K_{2 \mathrm{~s}} \mathrm{Y}_{\mathrm{t}}^{\cdot}-\mathrm{S}+\sum_{s=0}^{n 3} K_{3 \mathrm{~s}}(\mathrm{R}-\mathrm{R} \cdot \mathrm{M}){ }_{\mathrm{t}-\mathrm{s}}$

Where $\mathrm{K}_{\mathrm{i}}$ 's are the parameters.

\section{3- Forecast From Time Series Model:}

There are three different time series models used to forecast inflation : a univariate AR (Auto regressive) model, a traditional VAR (vector autoregressive ) and a VAR estimated with Bayesian techniques ( BVAR).

$\mathrm{AR}$ and VAR models are the most widely used time series techniques to forecast inflation which also yield reasonable good results. Bayesian techniques have the advantage over an AR or a traditional VAR that the problem of over flitting is avoided by imposing priors that assign a probability distribution to each coefficient. This reduces the amount of information required to estimate the model. (Rumler \& Valderrama, 2008) 


\section{Chapter 2: Inflation Targeting in the Emerging Economies:}

A growing number of Emerging Economies have adopted inflation targeting (IT) framework particularly since the late 1990s. The specific details and the circumstances that led to the adoption of the framework vary from country to country.

In some cases, the inflation targeting regime was implemented gradually, with the sequential introduction of the mechanisms that formally characterize the framework. In others, it was introduced rapidly, as a response to financial or currency crises that caused the abandonment of previous monetary arrangements and led to the search for new " nominal anchors" for monetary policy. (Libanio, 2010)

Inflation targeting is more difficult to implement in Emerging markets, because of five factors:

1- Emerging markets generally have weak fiscal institutions, which lead to fiscal dominance, i.e the lack of the ability to freely raise the interest rate because of the negative fiscal impact.

2- Emerging markets generally have weak financial institutions, which lead to financial dominance, i.e, the lack of the ability to freely raise the interest rate because of the fear of general bankruptcy of financial institutions. This also includes poor prudential regulation and supervision.

3- Emerging markets' institutions lack credibility, which may require too high an interest rate to achieve the inflation target, with negative impacts on output growth.

4- Many Emerging markets suffer from currency substitution and liability dollarization, which may seriously hamper the ability to let the exchange rate float.

5- Emerging markets are very vulnerable to the reversal of capital flows. Large external shocks cause large damages to the Emerging markets (external dominance).

Despite the challenges to getting inflation targeting to work successfully, inflation targeting has been successfully in promoting macroeconomic stability in a number of emerging market countries. Here we will look at two case studies, Chile and Brazil. (de janeior, 2006)

\section{Chile's Experience:}

Inflation was a major issue for the government in Chile. Its reduction was a matter of debate and public concerns for decades.

Chile is considered as the second country in adopting inflation targeting in the world, setting its first annual target in September 1990 for the following year. Since then, Chile's central bank has used inflation targeting to bring inflation down from $27 \%$ in 1990 to low stationary levels that are consistent with the indefinite target range of 2-4\% per year. (Kamal, 2010)

Furthermore, in 1999- 2000 the bank has upgraded its monetary framework to fullfledged inflation targeting.

Before embarking on inflation targeting, Chile passed new central bank legislation in 1989 (that took effect in 1990), which gave independence to the central bank and mandated price stability as one of its primary objectives. A sound fiscal policy was also in place, with the fiscal balance in surplus in every year from 1991 to 1997 . In addition, due largely to the 
measures taken in the aftermath of its severe banking crisis in the early 1980s, Chile's standards and practices in the areas of banking regulation and supervision were of a quality comparable to those found in industrialized countries. (Mishkin, 2000)

The Chilean experience with inflation targeting looks quite successful. Inflation fell from levels above $20 \%$, when inflation projections were first introduced, to a level around $3 \%$.

The reduction in inflation was correlated with satisfactory and stable economic growth rate during the inflation targeting period. Economic growth rate remained positive during most part of the inflation targeting period. Another benefit of inflation targeting in Chile is that it has been successful in lowering and stabilizing the interest rate to an average of 4\%. (Konanani, 2010)

It is important to emphasize that the success of inflation targeting cannot be solely attributed to the actions of the Chilean central bank: supportive policies such as absence of large fiscal deficits and rigorous regulation and supervision of the financial sector have been crucial to its success. Another important element of Chile's strategy has been gradual hardening of the targets over time. (Mishkin, 2000)

The Chilean experience with inflation targeting suggests that the inflation targeting framework was successful in attaining permanent low inflation rates even when the initial inflation rate was in double - digits. Perhaps these satisfactory results suggest that an inflation targeting strategy is useful even in emerging market countries by providing an effective nominal anchor for their economies. (Konanani, 2010)

\section{Brazil's Experience:}

Brazil followed a big ban strategy for the adoption of an inflation targeting framework, that is, inflation targeting was implemented in a very short period, making Brazil the first Latin American country to implement a formal inflation targeting framework. It took Brazil fewer than six months (March to June 1999) to introduce a full fledged inflation targeting framework after a brief period of exchange rate targeting that ended in a major crisis in 1998 and as part of an extensive programme of economic reforms. Formal inflation targeting was adopted in June 1999. (Konanani, 2010)

On the same date of the adoption of inflation targeting framework for the conduct of monetary policy, the president of Brazil has issued a decree instituting it.

The regime contains all the key elements of an inflation target strategy, namely;

1- The announcement of multi-year inflation targets with explicit numerical targets for the 12 months rate of inflation in the years 1999, 2000 and for 2002 onwards two years in advance.

2- Assigning to the National Monetary Council the responsibility for setting the inflation targets and tolerance ranges based on a proposal by the Minister of Finance

3- Giving to the Brazilian central bank full responsibility to implement the policies needed to attain the inflation targets.

4- Establishing procedures to increase the central bank's accountability; and

5- Taking actions to improve the transparency of monetary policy concretely. (Kamal, 2010)

The inflation rate was $8.9 \%$ and $6 \%$ for targets of $8 \%$ and $6 \%$ in 1999 and 2000 respectively; the targets were within the acceptable range. 
However, in 2001 and 2002, several external and domestic shocks- such as domestic energy crisis in Brazil, effects of Sep. 11, 2001, the Argentine crisis, and the confidence crisis related to the presidential election in 2002- hit the Brazilian economy with significant impacts on inflation. Indeed, the inflation rate reached $7.7 \%$ in $2001,1.7 \%$ above the target's upper range, and $12.5 \%$ in 2002, more than 5 percentage points above the upper range. (the levy Economics institute, 2005)

The inflation targeting mechanism has played a key role in macroeconomic stabilization in Brazil. In spite of large inflationary shocks, the inflation rate has been maintained at a low level.

There was an improvement in macroeconomic indicators in Brazil after the adoption of inflation targeting. The deficit in the current account has turned from a deficit of 18.4 billion of US\$ in 1995 into surplus of 4.2 billion of US\$ in 2003 and 1.7 billion of US\$ in 2007. Inflation rate has declined from $22.4 \%$ in 1995 to $4.5 \%$ in 2007 . Economic growth has reached $5.4 \%$ in 2007 compared to $4.2 \%$ in 1995. (Kamal, 2010)

Adoption of inflation targeting framework was a consequence to difficulties that the economy has faced and this framework helped to achieve confidence in the Brazilian economy and credibility of monetary policy.

The examples of Chile and Brazil illustrate that inflation targeting is indeed feasible in emerging market economies, despite their more complicated political and economic environment. This requires not only a focus on good communication and transparency by the central bank, but also supportive policies to develop strong fiscal, financial and monetary institutions.

\section{Chapter 3: Inflation Targeting in Egypt: \\ Overview of the Egyptian Monetary Reform: \\ First phase: ERSAP (1990-1996):}

Monetary reform during this phase could be summarized as follows:

1- Terminating most of the periods that distorted the capital markets (such as, interest rate ceiling) to help ensure an efficient allocation of financial resources.

2- Restructuring and strengthening the financial position, as well as increase competition in the banking system to help mobilize more of domestic saving through competitive positive real interest rates.

3- Marginalizing the CBE rule in financing treasury deficits by allowing more independent and active monetary policy. In this regard, a market for government securities was developed; this market for treasury bills provided an important substitute for treasure borrowing from CBE and it was considered an important monetary tool. (Maher, 2012)

\section{Second Phase: ERSAP (1996-2005):}

Since the conclusion of the stabilization program in 1996, the CBE was concerned with achieving multiple objectives simultaneously, which were conflicting in several instances. These objectives included attaining high economic growth while maintaining low inflation and preserving a stable exchange rate. The multiplicity of objectives in the presence of increasing capital mobility made conducting an independent monetary policy virtually impossible. 
Between 1996 and 2005, the CBE's operational target was excess reserves of banks, and given the strong link between monetary aggregates and inflation, growth in M2 was the intermediate target. (AL Mahat\& Billmeier, 2008). The second phase was characterized by tight monetary stance, that tightness based on the observed slowdown in the growth of M2 and the reserve money. (Maher, 2012)

\section{Third Phase: ERSAP (2005-2010) Towards Inflation Targeting :}

The CBE has made many important strides to upgrade Egypt's framework for conducting monetary policy to adopt inflation targeting.

The CBE launched a comprehensive and far reaching banking sector reform program in 2004. The reform program included the restructuring and privatization of banks with state participation, a new banking law and other regulatory reforms, the liberalization of the foreign exchange and money markets and efforts to strengthen the supervision of banks. (AL Mahat \& Billmeier, 2008). Several institutional and operational changes were initiated to help facilitate monetary policy formulation and assessment and lay the ground for formally adopting an inflation targeting.

Institutionally: the CBE established a Monetary Policy Committee (MPC) which convenes on Thursdays every six weeks to decide on key policy rate. The MPC consists of nine members: the Governor, the two deputy Governors and six members of the CBE's board of directors.

To enhance transparency, bolster the credibility of the CBE and help anchor inflation expectations, MPC'S decisions are communicated to the market through a monetary policy statement, which is released on the CBE'S external web site after each meeting.

Operationally: In 2005, the CBE introduced an interest rate corridor. The CBE'S two standing facilities: the overnight lending and a deposit facility. The interest rates on the two standing facilities define the ceiling and floor of the corridor, respectively. By setting the rates on the standing facilities, the MPC determines the corridor within which the overnight rate can be fluctuating.

\section{Is Egypt Ready for Inflation Targeting?}

We try to assess whether Egypt has satisfied the preconditions for an inflation targeting regime in such a way that it makes the adoption of an inflation targeting regime in Egypt feasible to anchor individuals' expectations around the potential inflation targets. In order to do that, we explore three elements:

- Independence status of the central bank

- Fiscal sustainability

- Accountability and Transparency.

- Forecasting capability

\section{1- Independence Status of the Central Bank:}

Law no.88/2003 and its amendment regulate the activities of the central bank in Egypt. According to the decree, the bank shall, in agreement with the government and through a coordinating council, set the targets of the monetary policy in a way that realizes price stability and banking system soundness, within the context of the general economic policy of 
the state. Other functions include the CBE's responsibilities for the supervision of payment systems, management of liquidity, international reserves and external debt.

Law no.93/2005, grants the CBE a higher degree of instrument independence, as it is free to set its discount rate and upper and lower limits for bank borrowing and lending rates and, in the absence of such limits, to make rules and directives to influence interest rate setting and credit expansion. However, the existence of government representatives as voting members on the monetary policy committee and the fact that the governor is appointed by the decree of the president for a short term of four years, reflecting that the CBE will be seen as not fully independent according to law. (Ghalwash, 2010)

To summarize, the CBE can still be seen as partially independent, with some indicators pointing to an implicit fiscal dominance. Thus, it is recommended to amend the relevant legislation to prohibit the monetary financing of fiscal deficits. A revision of the monetary policy committee membership and/or the limitation of the right of government members to vote are also highly recommended as ways of ensuring greater independence.

\section{2- Fiscal Sustainability (Public Debt Sustainability):}

One approach to assessing fiscal sustainability requires determining the debt stabilizing primary fiscal surplus for a given combination of growth and interest rates. This measure can be expressed as

$$
\mathrm{Pd}^{*}=(\mathrm{I}-\mathrm{g}) \mathrm{d}
$$

Where $\mathrm{Pd}^{*}$ is the primary deficit (as a ratio of GDP) required to stabilize the debt to GDP ratio for a given steady real interest rate (I), long run growth rate of real GDP (g), and initial stock of debt (d).

This indicator can help assess a given current fiscal policy by judging whether the existing primary balance is consistent with a stable debt to GDP ratio and indicating how much effort is required to achieve a stable debt ratio. The debt stock would be judged unsustainable if the ratio implies the need for adjustment efforts beyond those observed in the country's historical performance. (world bank, 2005)

Table (1)

Calculation of the Primary Deficit That Stabilizes the Debt To GDP Ratio (2006)

\begin{tabular}{c|c|c|c|c|c}
\hline \hline Targeted Debt to GDP Ratio & $\mathrm{I}$ & $\mathrm{g}$ & $\mathrm{d}$ & $\begin{array}{c}\text { Pd* }= \\
(\mathrm{It}-\mathrm{gt}) \mathrm{dt}\end{array}$ & $\begin{array}{c}\text { Primary Balance Gap } \\
\left(\mathrm{pd} \boldsymbol{w}^{*} \mathrm{pd}\right)\end{array}$ \\
\hline \hline $71.4 \%$ (Current) & 4.9 & 6.8 & 0.714 & -1.36 & 1.04 \\
\hline $60 \%$ & 4.9 & 6.8 & 0.6 & -1.14 & 1.26 \\
\hline $40 \%$ & 4.9 & 6.8 & 0.4 & -0.76 & 1.64 \\
\hline \hline
\end{tabular}

Source: CBE, world bank data base and author's calculation

We use the debt ratio of FY 2006 as the initial level of debt that has to be stabilized. Note that this does not necessarily imply that this level is sustainable. Indeed, current levels of public debt in Egypt are higher than considered prudent for developing countries and higher than the level at which many countries experience severe macroeconomic instability. 
Inflation Targeting in Emerging economies ...

Table (2)

Calculations Using 2005 to 2010 Real Interest Rate Levels

\begin{tabular}{c|c|c|c|c|c}
\hline \hline & $\mathrm{I}$ & $\mathrm{g}$ & $\mathrm{d}$ & $\begin{array}{c}\mathrm{Pd}^{*}= \\
(\mathrm{It}-\mathrm{gt}) \mathrm{dt}\end{array}$ & $\begin{array}{c}\text { Primary Balance Gap } \\
\left(\mathrm{pd}^{*}-\mathrm{pd}\right)\end{array}$ \\
\hline \hline 2005 & 6.5 & 4.5 & 0.6 & 1.2 & -1.1 \\
\hline 2006 & 4.9 & 6.8 & 0.6 & -1.14 & 1.26 \\
\hline 2007 & -0.1 & 7.1 & 0.6 & -4.32 & -4.02 \\
\hline 2008 & 0.1 & 7.2 & 0.6 & -4.26 & -3.56 \\
\hline 2009 & 0.7 & 4.7 & 0.6 & -2.4 & -3.6 \\
\hline 2010 & 0.8 & 5.1 & 0.6 & -2.58 & -2.28 \\
\hline \hline
\end{tabular}

Source: CBE, world bank data base and author's calculation

Table (2) uses the 2005 to 2010 real interest rate levels to calculate the primary deficit that stabilizes the debt to GDP ratio.

The importance of the primary gap indicator lies in its ability to measure the size of the adjustment needed in order to return the fiscal balance to its sustainable level. However, it does not answer the question of what adjustment is desirable.

Also compared to other emerging market countries that implement an inflation targeting framework, Egypt's budget deficit has been high and the level of public debt has been around 95 percent of GDP.

Table (3)

Fiscal Indicators in Egypt and Comparators

\begin{tabular}{c|c|c}
\hline \hline Country & IT Adoption & Fiscal Balance/ GDP \\
\hline \hline Chile & Sep 99 & 0.1 \\
\hline Czech republic & Jan 98 & -0.4 \\
\hline Turkey & Jan 06 & -7.0 \\
\hline Poland & Oct98 & -3.1 \\
\hline Brazil & Jun99 & -7.7 \\
\hline Egypt & & -9.1 \\
\hline \hline
\end{tabular}

*numbers for Egypt refer to the annual average between 2003-2006. 2003 marks the beginning of banking reforms

* number for the IT comparators are the four year averages prior to the adoption of IT

Source: Rania Al Mashat, Monetary policy in Egypt: a retrospective and preparedness for inflation targeting,

ECES, working paper no.134, 2008, p.22

\section{3- Accountability \& Transparency:}

Regarding the CBE, an effort has been made to strengthen communication with the public through the regular publication of monthly, quarterly and annual reports. Press releases on the main considerations underlying monetary policy decisions are also available on the CBE's website. The country's general economic situation is analyzed in the bank's regular publications, but these reports do not compare the outcomes of the monetary policy against the initial objectives, as this does not help in building credibility. A major step to enhance CBE transparency would be to issue an inflation report that includes an assessment of current and future economic developments for the public and analyses the major risk factors that are identified during each round of forecasts. Producing such a report, which explains the conduct of policy in more qualitative terms, would definitely reinforce credibility and confidence building. (Abdel Ghaffar, 2008) 
المجلة العربية للإدارة، مج 35، ع 2 - ديسمبر (كانون أول) 2015

Table (4)

Accountability in Selected Inflation Targeting Countries

\begin{tabular}{c|c|c|c|c}
\hline \hline Country & $\begin{array}{c}\text { Instrument } \\
\text { Independence }\end{array}$ & $\begin{array}{c}\text { Inflation Targeting } \\
\text { Explicitly in Law }\end{array}$ & $\begin{array}{c}\text { Target } \\
\text { Announcement }\end{array}$ & $\begin{array}{c}\text { Hearing in } \\
\text { Parliament }\end{array}$ \\
\hline \hline Brazil & Yes & No & $\begin{array}{c}\text { Set by National } \\
\text { Monetary } \\
\text { Council }\end{array}$ & No \\
\hline Chile & Yes & $\begin{array}{c}\text { Price Stability+ } \\
\text { Financial Stability }\end{array}$ & Central Bank & Yes \\
\hline $\begin{array}{c}\text { Czeh } \\
\text { Republic }\end{array}$ & Yes & Price Stability & $\begin{array}{c}\text { Government + } \\
\text { Central Bank }\end{array}$ & Yes \\
\hline Poland & Yes & Price Stability & $\begin{array}{c}\text { Central Bank } \\
\text { Government+ } \\
\text { Central Bank }\end{array}$ & Yes \\
\hline Turkey & Yes & Price Stability & No \\
\hline \hline
\end{tabular}

Source: IMF, on target? The international experience with achieving inflation targeting, IMF working paper,

WP/05/163, 2005, p.11

This table shows that in inflation targeting comparators in emerging markets the central bank has instrument independence. However, goal independence is not granted in all cases and has varied across countries. In some instances, the government and the central bank jointly decide on the target while in other cases that does not hold.

Also, the Egyptian authorities still have a lot to do in statistics to harmonize data, methodologies and compilation practices from different sources. Besides, the absence of a statistical office that is fully independent in the sense of institutional, financial and political independence can only be denounced. The existence of such an institution, endowed with sufficient financial and human resources, is crucial to ensure the credibility of the inflation targeting framework.

\section{4- Inflation forecasting capability in Egypt:}

The inflation forecast is central to inflation targeting regime and requires a welldeveloped technical infrastructure, including quality data, construction of an appropriate price index, and forecasting and modeling capabilities.

Regarding the quality of data, unreliability of data is one of the major problems facing econometric modeling and estimation in Egypt which incidentally is central to price inflation forecasting for inflation targeting. Even with so many reforms and improvement of the data collection in Egypt timely and reliable data availability remains an issue. (Ghalwash, 2010)

Also, the use of the consumer price index (CPI) in Egypt for evaluating the inflation behavior may serve as a useful tool, but it will be risky if the CBE is planning to use it for the purpose of inflation targeting. As in all developing countries, choosing such an index is problematic.

The first reason is that foodstuffs, which make up a large part of the basket, have highly variable prices because of their sensitivity to weather conditions. This high variability translates into more volatile CPI inflation.

Second, goods and services with subsidized prices have a substantial share of the basket. Large improvements in regulated prices, which have a direct impact on the overall price level, may lead to poor control of inflation and damage the central bank's credibility. (Ghalwash, 2010) 
According to a study ${ }^{(1)}$ that evaluate the three alternative approaches to forecasting inflation (output gap model, money gap model and time series model). The empirical results show that the three models result in poor forecast performance in Egypt during the period (2000-2004).

Table (5)

Comparison of Different Models' Inflation Forecasts

\begin{tabular}{c|c|c|c|c}
\hline \hline & Actual & Output Gap & Money Gap & Var Model \\
\hline \hline $\mathbf{2 0 0 1 : 1}$ & 2.36 & 1.71 & 3.70 & 1.77 \\
\hline $\mathbf{2 0 0 1 : 2}$ & 2.24 & 0.68 & 5.03 & 2.38 \\
\hline $\mathbf{2 0 0 1 : 3}$ & 2.16 & 0.74 & 5.61 & 4.49 \\
\hline $\mathbf{2 0 0 1 : 4}$ & 2.32 & -1.48 & 7.01 & 8.03 \\
\hline $\mathbf{2 0 0 2 : 1}$ & 2.60 & -0.69 & 7.75 & 8.30 \\
\hline $\mathbf{2 0 0 2 : 2}$ & 2.65 & 0.21 & 9.40 & 2.50 \\
\hline $\mathbf{2 0 0 2 : 3}$ & 2.73 & -1.65 & 9.98 & -3.57 \\
\hline $\mathbf{2 0 0 2 : 4}$ & 2.96 & -1.83 & 8.44 & -6.49 \\
\hline \hline
\end{tabular}

Source: Diaa Noureldin, alternative approaches to forecasting inflation in the case of Egypt, erf annual conference, 2005, p.20

The study conclude that having unreliable statistics (especially on inflation and aggregate demand) will hinder the operations of the CBE, inflation targeting is an information inclusive strategy; if available information is misleading, the success of inflation targeting in Egypt will certainly be compromised.

\section{Lessons from the Experience of Some Emerging Market Economies:}

\section{1- These Countries Were Seriously Keen on and Willing to Achieve the Goal of Price Stability:}

The real intention to achieve the goal of price stability was the stimulus behind the preparation for the adoption of inflation targeting policy in emerging countries. As such intension was real it was swiftly translated into tangible steps on the ground.

From Brazil experience, where the central Bank and the government became convinced with the adoption of inflation targeting as a means to achieve the goal of price stability, the preparation and the switching to the inflation targeting occurred during very limited time, i.e. during the period from March to June of the year 1999. (Awad, 2009).

\section{2- Improving Transparency and Accountability:}

The key to success of inflation targeting is its stress on transparency and communication with the public. (Mishkin , 2000).

Emerging economies improved private sector planning by reducing uncertainty about monetary policy, interest rates and inflation.

\section{3- Developing Strong Fiscal and Financial Institutions:}

Fiscal stability is a fundamental necessary condition for inflation control and hence inflation targeting.

(1) Diaa Noureldin, alternative approaches to forecasting inflation in the case of Egypt, erf annual conference, 2005. 
When markets recognize the weakness of the banking system, there will be a reversal of capital flows out of the country that will result in a sharp depreciation of the exchange rate which leads to upward pressures on the inflation rate. (Mishkin, 2004). Moreover, because of the currency devaluation, which most likely accompanies the monetary expansion, the debt burden of domestic firms, which are denominated in foreign currency rises, while the assets which are denominated in domestic currency do so at a much slower pace, thus leading to decline in net worth.

\section{Conclusion:}

Many countries have adopted inflation targeting as a framework for conducting their monetary policy. Initially adopted by industrial countries, inflation targeting has since been adopted by a large number of emerging market economies too, encouraged by its perceived success.

The examples of Chile and Brazil illustrate that inflation target is indeed feasible in emerging market economies, despite their more complicated political and economic environment. This requires not only a focus on good communication and transparency by the central bank, but also supportive policies to develop strong fiscal, financial and monetary institutions.

The main objective of this study is to answer whether Egypt satisfies the prerequisites for the inflation targeting regime. The conclusion came as follows:

- The Central bank is partially independent. Although the new legislation determined the primary objective of monetary policy to be achieving the goal of price stability and granted the CBE independent legal instrument. So, a revision of the monetary policy committee membership and the limitation of the right of government members to vote are highly recommended as ways of ensuring greater independence.

- Egypt suffers from a structural budget deficit. As a result, the debt keeps on growing which in turn places a burden on the government budget through interest payment.

- Also, it is important to work on improving the CBE's technical capabilities, including its forecasting capabilities and the statistical reporting system.

In the light of these results, the study concludes that the preconditions of inflation targeting are moderately met in Egypt. But Egypt needs more efforts to improve transparency and accountability and developing strong fiscal and financial institutions. 
Inflation Targeting in Emerging economies ...

\section{References}

- Abdel Ghaffar, Hoda. (2007). Towards Inflation Targeting in Egypt: Fiscal and Institutional Reforms to Support Disinflation Efforts, European Economy, Economic papers, No. 288.

- Al Mashat, Rania \& Billmeier, Andreas. (2008). The Monetary Transmission Mechanism in Egypt, ERF, Working Paper No. 411.

- Al Mashat, Rania. (2008) Monetary Policy in Egypt: a Retrospective and Preparedness for Inflation Targeting, ECES Working Paper No.134.

- Awad, Ibrahim. (2008). "Switching to the Inflation Targeting Regime: the Case of Egypt", Journal of Economics and Business, Vol. XI, No. 1 \& 2, p.106-131.

- Awad, Ibrahim. (2009). Is Egypt Ready to Apply Inflation Targeting Regime. Institute of Economic studies Charles University, p.141-159

- Batini, Nicoletta \& Kaxion, Douglas. (2006). Under What Conditions Can Inflation Targeting Be Adopted?, The Experience of Emerging Markets, Central Bank of Chile, Working Paper No. 406.

- Ghalwash, Tarek. (2010). An Inflation Targeting Regime in Egypt: A Feasible Option?, Modern Economy, 1, P. 89-99.

- IMF. (1998). Preliminary Considerations of An Inflation Targeting Framework For the Philippines, Working Paper No. 39.

- IMF. (2002). Establishing Initial Conditions in Support of Inflation Targeting, IMF Working Paper No. 102.

- Kamal, Mona. (2010). Inflation Targeting in Brazil, Chile and South Africa: An Empirical Investigation of Their Monetary Policy Framework, William Davidson institute, Working Paper No. 1004.

- Konanani, Patric. (2010). Is Inflation Targeting An Appropriate Framework For Monetary Policy? Experience From the Inflation Targeting Countries, Master Thesis, University of South Africa.

- Libanio, Gilberto. (2010). "A Note on Inflation Targeting and Economic Growth in Brazil", Brazilian Journal of Political Economy, September, P.1-14.

- Maher, Sherief. (2012). "Evolution of Monetary Policy in Egypt: A Critical Review", The International Journal of Social Sciences, November, Vol. 4, No. 1, P. 9-36.

- Mehra, Yash (1988), "The Forecast Performance of Alternative Models of Inflation", Economic Review, Sep. /Oct., P. 10-18.

- Mishkin, Frederic. (1998). International Experiences with Different Monetary Policy Regimes, seminar Paper No. 648.

- Mishkin, Frederic. (2000). From Monetary Targeting to Inflation Targeting: Lessons From the Industrialized Countries, Columbia University.

- Mishkin, Frederic. (2000). Inflation Targeting in Emerging Market Countries, National Bureau of Economic Research, Working Paper No. 7618.

- Mishkin, Frederic. (2004). Can Inflation Targeting Work in Emerging Countries, NBER Working Paper, Series No. 10646.

- Noureldin, Diaa. (2005). Alternative Approaches to Forecasting Inflation in the Case of Egypt, ERF Annual Conference.

- Roger, Scott \& Stone, Mark. (2005). On Target? The International Experience with Achieving Inflation Targets, IMF Working Paper No. 163.

- Rumler, Fabio \& Valderrama, Maria. (2008). Comparing the New Keynesian Phillips Curve with Time Series Models to Forecasts Inflation, Osterreichische National Bank, Working Paper No.148.

- Stock, James and Watson, Mark. (2005). Phillips Curve Forecasts.

- The Levy Economics Institute of Bard College. (2008). Inflation Targeting in Brazil, Working Paper No.544.

- Tutar, Eser. (2002). Inflation Targeting in Developing Countries and Its Applicability to the Turkish Economy, Master Thesis, Faculty of the Virginia Polytechnic Institute and State University.

- Vasilescu, Maria. (2010). Inflation Targeting between Theory and Reality, Annals of the University of Petrosani, Economics, 10 (3). P.357-364.

- World Bank. (2005). Fiscal and Public Debt Sustainability, Egypt Public Expenditure Review. 